\title{
Quantitative response of riverine benthic invertebrates to sediment grain size and shear
}

\section{stress}

Stefan Lorenz (1) https://orcid.org/0000-0002-2785-3404, Christian Wolter (1) https://orcid.org/0000-0002-2819-2900

DOI

10.1007/s10750-019-3908-9

Original publication date

15 February 2019

Document version

Author's accepted manuscript version

\section{Published in}

Hydrobiologia

\section{Citation}

Lorenz S, Wolter C. Quantitative response of riverine benthic invertebrates to sediment grain size and shear stress. Hydrobiologia. 2019;834(1):47-61. 
1 Running head: Invertebrate response to sediment \& flow

2

Title: Quantitative response of riverine benthic invertebrates to sediment grain size and shear stress

Authors: Stefan Lorenz ${ }^{1, *}$ and Christian Wolter ${ }^{2}$

Stefan Lorenz: Leibniz-Institute of Freshwater Ecology and Inland Fisheries, Department Biology and Ecology of Fishes, Müggelseedamm 310, 12587 Berlin, Germany.

Julius Kühn-Institut, Federal Research Centre for Cultivated Plants, Institute for Ecological Chemistry, Plant Analysis and Stored Product Protection, Königin-Luise-Str. 19, 14195 Berlin, Germany * corresponding author: stefan.lorenz@julius-kuehn.de

Christian Wolter: Leibniz-Institute of Freshwater Ecology and Inland Fisheries, Department Biology and Ecology of Fishes, Müggelseedamm 310, 12587 Berlin, Germany.

\footnotetext{
${ }^{1}$ stefan.lorenz@julius-kuehn.de, ${ }^{2}$ wolter@igb-berlin.de
}
Abstract
The most widespread pressure impacting river ecological status is the degradation of key hydromorphologic elements, such as sediment type and flow rate. However, almost nothing is known about the quantitative relationship between benthic invertebrate abundance and these elements. This synthesis compiles quantitative data on physical requirements and thresholds for invertebrates relative to two hydromorphologic factors: substrate size and hydraulic 
energy (measured as shear stress). Both factors are commonly a focus of river rehabilitation. However, we found only limited literature data that we could use to identify invertebrate preferences (189 taxa). Preferred substrate sizes of all stream epifauna we examined varied between 0.05 and $400 \mathrm{~mm}$ and that they prefer shear stresses from 0.13 to $3.67 \mathrm{~N} \mathrm{~m}^{-2}$. There was no difference in variation of preferred conditions between the examined taxonomic levels. We suspect that taxa preferring hydraulic environments with shear stresses $<0.64 \mathrm{~N} \mathrm{~m}^{-}$ 2 are affected more by environmental factors than solely being constrained by substrate or hydraulic energy preferences. Such taxa might be useful as sensitive indicator species for evaluating stream integrity. Hence, to optimize restoration success for riverine biota, hydromorphological forces should be mitigated by manipulating habitat complexity in a way that it enhances intact ecological processes.

\section{Keywords:}

hydraulic preference, hydromorphology-biota interaction, indicator species, river integrity, substrate preference 


\section{Introduction}

Worldwide, hydromorphologic (the simultaneously operating processes of hydrology and morphology) and habitat alterations have been identified as the most significant pressure impacting the ecological integrity of riverine ecosystem, riverine biodiversity, and water quality (USEPA, 2009; Vaughan et al., 2009; EEA, 2012; Fehér et al., 2012; Elosegi \& Sabater, 2013). An exponentially increasing number of river restorations have been attempted to enhance the hydromorphologic condition of riverine ecosystems (Bernhardt et al., 2005; Roni et al., 2005; Wolter, 2010; Palmer et al., 2010; Feld et al., 2011), but many of them have failed to reach their objectives. Restoration failure is commonly ascribed to the inappropriate spatial scale at which restoration activities are implemented (Sponseller et al., 2001; Kail \& Hering, 2009), poor or neglected habitat enhancement during restoration (Miller et al., 2010; Hering et al., 2015), or the confounding impacts of multiple stresses at a variety of scales (Weigel et al., 2003; Robson \& Mitchell 2010; Roni et al., 2008; Feld \& Hering, 2007; Lorenz \& Feld, 2013; Verdonschot et al., 2013). However, we currently lack a mechanistic understanding of how species respond to specific hydromorphologic conditions or how essential habitats or relevant bottlenecks are affected by hydromorphology (e.g., Wolter et al., 2004), thus leading to failure of some restoration projects.

Appropriate hydraulic flow and habitat structure are the two most significant parameters determining the ecological integrity of river epifauna, both of which are influenced by the interplay of river flow and channel morphology (Lorenz et al., 2016a). Dynamic flow is a hydraulic process that controls geomorphic patterns and variables and subsequently the composition of aquatic biota at various spatial and temporal scales (Frissell et al., 1986; Robson \& Chester, 1999; Chessman et al., 2006; Milner et al., 2015). Feld et al. (2011) provided numerous conceptual models to illustrate the variety of potential mechanisms and interactions that are possible (at various spatial scales) among hydrologic regime, 
geomorphology, biota, water chemistry, and suspended load. However, such multi-linkage models have rarely been used to predict interactions in any measurable or quantifiable way, at not least at a scale that could be used to inform rehabilitation planning. Notable exceptions include Janauer et al. (2010), who reported that species-rich and diverse communities of macrophytes might not tolerate flow velocities $>0.3 \mathrm{~m} \mathrm{~s}^{-1}$. Similarly, Wolter and Arlinghaus (2003) determined that fish hatchlings require flows $<0.1 \mathrm{~m} \mathrm{~s}^{-1}$, whereas juveniles cannot tolerate flows $>0.5 \mathrm{~m} \mathrm{~s}^{-1}$. In contrast, Statzner et al. (1988) and Söhngen et al. (2008) determined that rheophilic invertebrates could tolerate flows from 0.3 to $1.0 \mathrm{~m} \mathrm{~s}^{-1}$. However, such thresholds widely vary among higher taxa and even within genera (e.g., $<0.8 \mathrm{~m} \mathrm{~s}^{-1}$ for gastropods, $>1.5 \mathrm{~m} \mathrm{~s}^{-1}$ for some dipterans, and $>2.0 \mathrm{~m} \mathrm{~s}^{-1}$ for some beetles (Statzner et al., 1988). Limnophilic species prefer substantially lower flows (e.g., $<0.2 \mathrm{~m} \mathrm{~s}^{-1}$ ). Rheobiont macroinvertebrates that prefer flow velocities $>1 \mathrm{~m} \mathrm{~s}^{-1}$, are rather rare (Söhngen et al., 2008). Discharge (the volume of water discharged per unit time) and flow regime (both of which interact with valley and channel form) are extremely important in shaping hydromorphologic features and structures (Poff et al. 1997, Lorenz et al. 2016a). However, aquatic organisms typically do not respond to discharge directly, rather they typically respond to flow velocity and shear stress at their point of attachment. Both flow velocity and shear stress can limit habitat utilization by organisms. High flow rate and stream power regulate sediment transport and sorting. Hence, the array of substrate types formed by flow-induced sediment sorting processes are predictable and specific to a given type of hydraulic regime (Davis \& Barmuta, 1989). Therefore, substrate characteristics may be useful for indicating hydromorphological integrity. Likewise, because specific taxa are associated with specific substrate types (which in turn indicate functioning fluvial processes), the taxa could be used to indicate hydromorphologic conditions. 
Benthic invertebrates may be particularly useful as indicator taxa because their

distribution is determined by primarily hydraulic and/or substrate conditions (Hart \& Finelli, 1999; Jowett, 2003; Gabel et al., 2012). Invertebrates are commonly used as water quality indicators in ecological assessments; under European environmental legislation, they are an obligatory biological quality component (Birk et al. 2012; Lyche-Solheim et al., 2013).

However, little detailed information is available about the types of substrates stream invertebrates prefer or the shear stresses they can tolerate. For this reason, habitat preferences of stream invertebrates are commonly expressed in more qualitative terms provided in traitdatabases (e.g., lithal and rheophilic) (Schmidt-Kloiber \& Hering, 2015). In addition, substrate types and flow regimes are usually not very homogeneous in streams; rather, they are patchily distributed and occur at small spatial scales. This small-scale heterogeneity, combined with the high mobility of biota, may hamper the identification of indicator species that possess tolerances for specific hydromorphological conditions.

Some low-gradient river systems are naturally dominated by fine sediments (Downes et al., 2006) or have low oxygen concentrations (Sundermann et al., 2011a). In such systems, aquatic communities might tolerate sub-optimal substrate conditions if patches of limiting resources (such as food or oxygen) occur there (Downes et al., 2006; Robson et al., 1999). Additionally, substrate preference and small-scale distribution of invertebrates (such as shredder or collectors) are associated with the presence or absence of particular types of food resources (Culp et al., 1983; Williams \& Moore, 1986). Substrate characteristics are known to influence food-web structure (Power et al., 2013) and determine the distribution of invertebrate larvae by influencing the types of habitats available for egg laying (Downes \& Lancaster, 2010). However, invertebrate presence is not exclusively controlled by substrate characteristics; it is also influenced by how organisms interact with confounding environmental factors (Jowett, 2003). Unfortunately, it is difficult to determine to what degree 
a species' presence is related to its hydraulic preferences, availability of food resources, oxygen demand ,or some combination thereof (e.g., Lorenz et al., 2016a), particularly because species-specific data on biological requirements are unavailable for most species (Tyler et al., 2012). Hence, river restoration needs also information if biological requirements from higher taxonomic levels may potentially be transferred to species level if species data are unavailable.

This study focuses on the physical thresholds of shear stress in rivers and evaluates the relationship to sediment size and distribution of riverine benthic invertebrate epifauna (hereafter called invertebrates), even though these variables form only a small but highly relevant component of hydromorphology (Williams \& Hynes, 1974; Rabeni \& Minshall, 1977; Reice, 1980). Therefore, this study aims to develop a mechanistic understanding of the effects that key hydromorphologic variables have on invertebrate distributions to provide baseline information that can be used for planning successful river rehabilitations. We are well aware that invertebrate life histories and other factors, such as food preferences, also determine species-habitat relationships; however, each species reacts to dynamic flow and shear stress in its own way (e.g., suspension feeders obligatorily depend on flow) (Chester \& Robson, 2011; Growns \& Davis, 1994).

The main objectives of this synthesis were to (1) determine tolerance thresholds of physical forces limiting habitat suitability for riverine epibenthic species, (2) identify epibenthic species sensitive to variations across a wide range of hydromorphologic conditions, and (3) derive significant information if biological traits from higher taxonomic levels may potentially be transferred to species level.

\section{$\underline{\text { Methods }}$}


143 We acquired data from 12 studies (Online Resource 1) that used FST-

144 (FliesswasserStammTisch) hemisphere numbers to assess invertebrate hydraulic preferences

(e.g. Dolédec et al., 2007; Mérigoux et al., 2009). FST hemisphere studies use a set of 24 density (Statzner et al., 1991). Movement of the heaviest hemisphere at the stream bottom determines the shear stress acting at that location on the sediment surface. FST hemisphere numbers are converted to bed shear stress values according to Statzner et al. (1991). The shear stress measured at any given location can be used to determine the hydraulic preference of invertebrates inhabiting that particular hydraulic regime. Therefore, bed shear stress values can be used to predict suitable habitat for any invertebrate species across an array of potential fluvial environments (Gore, 1996; Möbes-Hansen \& Waringer, 1998). Shear stress accounts for turbulence at near-bed surfaces generated by sediment roughness, which creates drag and lift forces acting on invertebrates inhabiting the substrate (Möbes-Hansen \& Waringer, 1998; Mérigoux \& Dolédec, 2004). Although the available FST hemisphere numbers were obtained

157 for rivers and streams of various sizes, the hydraulic habitat preferences obtained seemed generally applicable as discussed by Lamouroux et al. (2012). We also explicitly included in our analysis taxa with low strength $\left(\mathrm{r}^{2}\right)$ of the average taxa preference model (sensu Mérigoux et al., 2009). Unusual or unexpected hydraulic/substrate combinations resulting from such low strengthes of taxa preference models might be indicative for taxa responses to particular ecological resource rather than to substrate type or flow condition in a stream (Kakouei et al., 2017). We reviewed additional information on flow velocity preferences for biota using the AQEM/STAR macroinvertebrates database (Schmidt-Kloiber \& Hering, 2015; www.freshwaterecology.info) and additional scientific literature. Furthermore, we compiled 
available data on the average shear stresses necessary to detach and dislodge invertebrates based on a Web of Science search.

We reviewed data from three studies that provided information on sediment habitat requirements of a large number of invertebrate species. Two studies, Tolkamp (1982) and Singh et al. (2010), provided an index of representation (IR), which provided habitat preferences or avoidance of habitats relative to specific grain size fractions (expressed as Phi indices) for a range of species. [The Phi index is the negative binary logarithm of particle size (Krumbein \& Sloss, 1963).] Hence, we associated IR values for each taxon with the Phi indices provided in these studies and converted the indices to grain size fractions. The third study, Schröder et al. (2013), provided substrate preferences based on multi-level pattern analysis.

\section{$\underline{\text { Data analysis }}$}

To investigate whether the variation in hydraulic and substrate preferences differed among taxonomic levels (family, genus, and species) identified for each preference group, we first compared the interquartile ranges (IQR) of each genera's hydraulic and substrate preferences to the IQR of the family for the genus. Due to the lack of enough available hydraulic and substrate preference data for both taxonomic levels, family and genus, we limited our comparisons to 13 families with 16 genera for substrate preferences and to 19 families with 18 genera for hydraulic preferences. Then we applied one-sided Wilcoxon tests (wilcox.test function, stat package, R statistical language, version 3.2.4) (R Core Team, 2015) to the IQRs to assess whether preferences were more variable within families than within genera. To identify species whose presence were not likely determined primarily by hydromorphic differences (substrate type or hydraulic preference), we plotted shear stress relative to substrate classes (from 0 to 11) (sensu Singh et al. (2010), see Table 1 for 
assignment of substrate class to grain size). Due to the very low number of species for which we could obtain data for both hydraulic and substrate preference data, we had to pool most species with other members of their genus, tribe or subfamily (e.g., dipterans and particularly chironomids) to obtain a large enough sample size $(n \geq 42)$. Some species show a large range of preferred grain sizes, e.g. the taxon Rhithrogena sp. shows a range of preferred grain sizes from 0.6 to $400 \mathrm{~mm}$ (Online Resource 3), which corresponds to a range of substrate classes from 0 to 8 . We are aware that using mean values for a variety of related taxa will mask the narrow substrate preferences of specialist species and possibly artificially exaggerate variation in more generalist taxa. However, the lack of sufficient data has required this step. We averaged substrate class preferences by season (Singh et al. 2010), and we used median values for species and/or genera for which more than one substrate class or hydraulic preference has been identified. We excluded taxa for which there were no preferences reported. Because an exponentially decaying regression model provided the best fit for our raw data, we squareroot transformed our data to make them linear and then performed a linear regression with a statistical outlier analysis to identify species and genera whose occurrence was most probably influenced by factors other than substrate type or shear stress. Outlier analysis was performed using functions in the car statistical package (Fox \& Weisberg, 2011) with Cook's distance and hat-values. Hat-values exceeding threefold the average hat-value, combined with Cook's distances values $>4 / n$, were considered outliers and removed from later analyses. We used hat-values exceeding half of the abovementioned common thresholds (1.5 times the average hat-value and Cook's distance values $>2 / n$ ) to identify species and genera whose occurrences are most probably determined by environmental factors other than substrate or shear stress. In so doing, we identified 13 outliers with our stepwise outlier approach (Online Resource 2), all of which we discuss in our chapter on environmental co-variables determining species presence. 
217 2012), we analyzed the trimmed data set to determine the average shear stress threshold, which we assumed could be used to define the habitat suitability for the species. Piecewise regression analysis (also known as segmented regression or broken-stick regression) is a type of regression analysis where the response variable is partitioned into intervals to which subsequently separate regressions are fit. This allows one to calculate critical thresholds along a response curve, which can identify specific thresholds of preferred shear tolerance among taxa. In addition, we performed a lognormal species sensitivity analysis to determine the average shear stress preferences of the entire data set using the fitdistr function from the MASS package (Venables \& Ripley, 2002). This sensitivity analysis was done to identify the percentage of species limited by habitat suitability constraints, which we assumed would occur at the average shear stress preference larger than the critical threshold identified by the piecewise regression.

\section{Results}

\section{$\underline{\text { Variability in hydraulic and substrate preferences }}$}

Two data sets were compiled for invertebrate species, one comprised of 215 hydraulic shear stress preferences for 188 invertebrate taxa in 63 families (Online Resource 1); the other data set was comprised of 209 substrate preferences and 189 sediment grain size preferences

(Online Resource 3). Preferred sediment grain sizes ranged from 0.05 to $400 \mathrm{~mm}$ and preferred shear stress values ranged from 0.13 to $3.67 \mathrm{~N} \mathrm{~m}^{-2}$.

Variations in hydraulic preferences did not differ significantly $(\mathrm{p}=0.09)$ among species within the same genus or family (median IQR at genus level $=1.9$, median IQR at family level = 2.7). However, hydraulic preferences may vary among families within the same 
order, which is illustrated by the example diagrams (whisker plots) of hydraulic preferences for five major invertebrate groups, pooled by genus or family (Fig. 1). The Wilcoxon rank sum test revealed a slight trend toward higher median IQR scores at the genus level than at higher taxonomic levels. As a result, our assessment of preferences at taxonomic levels higher than families may have grouped together species with significantly different flow requirements (e.g., Elmidae and Dytiscidae (Fig. 1)). Substrate preferences did not vary significantly $(\mathrm{p}=0.51)$ between species within the same genus or family (median IQR at genus level = 5, median IQR at family level =5), due to the large range in IQRs in both groups.

\section{$\underline{\text { Flow resistance thresholds }}$}

We identified six studies that provided data on tolerated shear stresses for 27 taxa (Online Resource 4), all of which considered variations in body size (Schnauder et al., 2010; Hauer et al., 2012) or the habitat wherein the individuals were located at the moment the drift causing event occurred (Borchardt, 1993; Gabel et al., 2012). For 14 of these 27 taxa, data were available for both hydraulic preference and critical shear stress (Online Resources 1 and 4). Although our comparisons show that the dislodging shear stress exceeds the preferred conditions for most species (as expected), the opposite relationship is seen for the caddisfly Rhyacophila spp. and the mayflies Epeorus sylvicola and Rhithrogena semicoloranta (Online Resource 4). This seemingly difference in tolerances might have been due to the responses of species to other environmental factors that influence their distributions (as illustrated by Rhitrogena sp. in Fig. 2), such as oxygen requirements.

\section{$\underline{\text { Relationship between preferred substrate size and shear stress }}$}


The regression model of substrate preferences plotted against shear stress preferences yielded preference relationships for 41 taxa and two groups of outliers (Fig. 2). Taxa in the upper part of the graph are outliers (Pisidium sp., Elmis sp., the caddisfly Philopotomus sp., the mayfly Rhithrogena sp., and the chironomids Tanytarsini gen. sp., Tanypodinae gen. sp. and Polypedilum breviantennatum) that prefer finer substrates than indicated by their shear stress preferences. In contrast, in the lower part of the graph, taxa such as Amphinemura sp., Perla sp. and Caenis sp. prefer coarser substrates than their shear stress preferences suggest. The presence of these outlier taxa may result from environmental factors that can only be provided under conditions where ecological processes are intact, thus suggesting that the taxa could serve as sensitive indicator species when evaluating alteration to hydromorphological integrity (see Discussion).

\section{Thresholds of physical forces limiting habitat suitability}

Our piecewise regression model identified a shear stress of $0.64 \mathrm{~N} \mathrm{~m}^{-2}$, which represents the physical threshold limiting the habitat suitability of species (Fig. 2). This suggests that of the 188 taxa we analyzed, $39 \%$ are potentially affected by limited habitat suitability where shear stresses exceed $0.64 \mathrm{~N} \mathrm{~m}^{-2}$ (Fig. 3).

\section{Discussion}

In general, there is very limited quantitative data available on species' responses to hydromorphological conditions in streams (Wolter et al., 2015). Of the approximately 20,000 European freshwater invertebrate species described, we found quantitative data on substrate size preferences for only 189 taxa and hydraulic preferences for 188 taxa. Although this sample comprises a rather small proportion of all known freshwater invertebrate taxa in Europe, our data set is still the largest compilation available on the relationship between 
sediment size and shear stress tolerances for stream invertebrate taxa. This small sample size is problematic because environmental assessment protocols, such as the PERLODES assessment system, rely on life history data of approximately 1100 invertebrate taxa (Meier et al., 2006).

\section{$\underline{\text { Hydraulic and substrate preferences }}$}

Our results show that hydraulic and substrate preferences of invertebrate species vary widely within taxonomic orders, among families within the same order, but not at the family and genus levels. We found that trichopterans and ephemeropterans, groups that are frequently targeted in river restoration (Lorenz et al., 2016b), show large interspecific variations in their hydraulic preferences. However, for for planning restorations, it would be useful if there were indicator species available that could better diagnose ecological conditions (Monk et al., 2012).

Variations in substrate size have been shown to be a significant predictor of invertebrate diversity (Waters, 1995; Angradi, 1999; Buss et al., 2004; Jowett, 2003). Our results show a slight trend of taxa showing higher variation in substrate preferences at the family level than at the genus level, a difference that might become more pronounced as more data become available. Erosion and deposition of fine sediments and organic matter influence the abundance of invertebrates (e.g., the abundance of Ephemeroptera, Plecoptera and Trichoptera species decline in finer mineral substrates) (Reice, 1980; Maxted et al., 2003; Beauger et al., 2006; Allan \& Castillo, 2007; Timm et al., 2008; Duan et al., 2009; Pan et al., 2012). These reported finding suggests that higher habitat heterogeneity and complexity are associated with higher invertebrate diversity (Buss et al., 2004).

Although other studies have found only minor effects of habitat improvement on benthic invertebrate diversity, habitat improvement has been shown to exert large effects on 
dispersal ability of local species pools (Sundermann et al., 2011b; Tonkin et al., 2014).

However, none of those habitat-improvement studies included detailed information on the effect of preferred shear stress or substrate availability on diversity, even though substrate condition is known to affect benthic invertebrate assemblages, especially following stream restoration (Jähnig \&Lorenz, 2008; Lorenz et al., 2009). Ideally, a river restoration should provide a variety of habitats that provide the suite of desirable grain sizes preferred by epifaunal species, even though environmental stresses may still exist or even prevail at the catchment scale (e.g. Sundermann et al., 2013). Based on our data, river restoration designs could explicitly provide a variety of hydraulic conditions that would generate a variety of substrate sizes. These substrates could be generated by creating structures in channels, such as riffles, pools, coarse wood, and river banks (Lange et al., 2015), which could be designed to meet habitat requirements of specific target species. Our results indicate that if detailed information on target species is unavailable for restoration planning, then data for families could be used to select hydraulic and substrate targets.

\section{$\underline{\text { Flow resistance thresholds }}$}

Critical flow velocities, which define the thresholds at which invertebrates become detached and dislodged, are typically much higher than their preferred flow velocities (Söhngen et al., 2008). However, data shown by Söhngen et al. (2008) indicated that a surprisingly high number of invertebrate species are able to resist flow velocities close to their detachment thresholds. The shear stress data we collected had been measured in rivers of various sizes and using various methods, and this may account for some of the variation we encountered. However, particle size variations in substrates (at small scales) may also explain why different species exist in different hydraulic environments. Hydraulic preferences for species adapted to higher shear stress than their critical shear stress (which induces dislodgement) (e.g., for 
Rhyacophila spp., E. sylvicola, and R. semicoloranta) were derived from surveys in the large Upper Rhône River (France) (Mérigoux et al., 2009). However, critical shear stress thresholds for these species were determined from individuals sampled in the much smaller Ybbs River (Austria) (Hauer et al., 2012). Apparently, hydraulic preferences of epifaunal species (shear stress, but also water depth and velocity) vary with river size (Jowett, 2000; Mérigoux et al., 2009). However, higher critical shear stress thresholds might also be related to the interaction of increasing flow velocity with higher bed instability [e.g., Baetis sp. inhabited conditions ranging from $0.26 \mathrm{~N} \mathrm{~m}^{-2}$ to $9 \mathrm{~N} \mathrm{~m}^{-2}$ (Gibbins et al., 2010; Hauer et al., 2012)]. Species probably benefit when they can access low flow areas (refuges) in interstitial spaces of coarse substrates. When coarse sediments are washed away, organisms are more likely to detach and drift downstream.

Critical flow velocities and shear stresses needed to dislodge invertebrates also vary considerably, depending on the body shape and size of the organism. Larger specimens are typically more likely than smaller individuals and juveniles to actively resisting high hydraulic forces (Schnauder et al., 2010; Hauer et al., 2012). Additionally, species might respond differently to a slow and continuous increasing of hydraulic stress by actively avoiding areas of high flow. For example, some species respond by burrowing deeper into the sediment or by adjusting body postures to minimize drag when flow conditions gradually exceed some threshold rate (Poole \& Stewart, 1976; Statzner, 1981; Holomuzki \& Biggs, 2000; Schnauder et al., 2010). In contrast, abrupt changes in hydraulic conditions are more likely to dislodge invertebrates than gradual increases of flow velocity, discharge, or shear stress (Imbert \& Perry, 2000).

Our results indicate that behavioral responses to high flow conditions are speciesspecific and do not occur in all invertebrate species. For example, the damselfly Calopteryx splendens can resist a gradual increase in shear stress of $2.4 \mathrm{~N} \mathrm{~m}^{-2}$ in sand by 
adopting a drag-minimizing body posture (Schnauder et al., 2010), but can be dislodged by an abrupt change in shear stress of only $0.13 \mathrm{~N} \mathrm{~m}^{-2}$ (Gabel et al., 2012) (Online Resource 3). However, peak shear stress conditions seem to be the primary cause for dislodgement of taxa that are unable to attach to a sediment surface (Online Resource 4). This interpretation is supported by the behavior of the gastropod Bithynia tentaculata, which is dislodged at shear stresses between 0.44 and $0.57 \mathrm{~N} \mathrm{~m}^{-2}$, whether stress increase is gradual or abrupt (Online Resource 4). This example suggests that mobile species are able to adapt behaviorally to gradual increases in flow more so than sessile species. However, other gastropods can quickly produce mucus to anchor themselves (a behavior not observed for B. tentaculata) when shear stresses increase above a particular threshold (Schnauder et al., 2010). Even after dislodgement, remaining mucus threads provide an adhesive anchorage that prevents the snails from drifting very far downstream, suggesting that some gastropod species might also possess species-specific resistance behaviors (Schnauder et al., 2010) that may affect hydraulic and substrate preferences.

\section{$\underline{\text { Relationship between preferred substrate size and shear stress }}$}

Our results identified nine taxa not following the estimated shear stress/substrate relationship in the upper part of Fig. 2. Most of those nine taxa have been well documented as having extremely high dissolved oxygen requirements. For example, riffle beetles (Elmidae: Elmis sp.) prefer cool, fast-flowing streams and rivers, conditions in which water is almost completely saturated with oxygen (Elliott, 2008). Likewise, the mayfly Rhithrogena sp. typically occurs in rapidly-flowing, oxygen-rich waters and is sensitive to low dissolved oxygen concentrations that occur in slowly flowing water (Ambühl, 1960), whereas chironomid species of tanytarsini (Micropsectra sp.) and tanypodinae (Procladius sp.) are sensitive to intermediate dissolved oxygen conditions (Bérg et al., 1962; Johnson, 1995; 
Quinlan \& Smol, 2001; Brodersen et al., 2008). In contrast, sphaeriids of the genus Pisidium sp. are resistant to hypoxia, but they depend on locally available oxygenated microhabitats within sediments where they can persist during hypoxic events (Mackie, 2007).

For stream epifauna species that require highly oxygenated conditions, oxygen concentration may be more important to them than size of substrate material (Fig. 2). However, our results show that such species seem to prefer finer substrates than would be expected to occur in high shear stress environments (Fig. 2). This holds true despite we even had to pool species that show a large range of preferred grain sizes, e.g. the taxon Rhithrogena sp. (Online Resource 3). The available preferred substrate data of this species vary between investigated seasons, with larger substrate preferences in spring (cobbles) compared to other seasons. Spring is this season where large amounts of fine sediment are flushed from the stream channel due to rain events and snow melting. Similarly, this species prefers larger sediments in mountain areas (where large sediments such as boulders or cobbles are dominating), while it prefers finer sediment in other areas. This strongly points on the interpretation that the presence of this species is not primarily driven by hydromorphological constraints, even though substrate preferences may match hydraulic preferences in certain areas (mountain) or seasons (spring) of the year. To cope with this trade-off between preference for fine substrates and high oxygen availability, these species probably seek moderately flushed, but well oxygenated interstitial spaces that provide them both shelter from high flow conditions and access to fine substrate.

We found that some taxa had been characterized by significantly lower shear stress tolerance than would have been expected by their preferred substrate type (Fig. 2). For example, the taxa Amphinemura sp. and Perla sp. are strong biofilm grazers (Graf et al., 2007; Graf et al., 2009), which might explain their preference for large substrate size where biofilm tend to grow. Likewise, although Singh et al. (2010) reported that Caenis sp. is associated with large 
stones and boulders, the species is a detritivore, which means it typically seeks patches of organic detritus and decaying leaves (Int Panis et al., 1994; Pabst et al., 2008) that typically accumulate between boulders in slowly to moderately flowing rivers. Therefore, the preference of Caenis for boulders identified by Singh may primarily reflect the species preference for organic food resources rather than a preference for inhabiting large substrate (Bradbeer \& Savage, 1980). Other taxa showing preferences for unusual or unexpected hydraulic/substrate combinations might actually be responding more strongly to a particular resource or oxygen availablility than to substrate type or flow condition in a stream (Kakouei et al., 2017). Such taxa might be useful as sensitive indicator species for evaluating ecological conditions (and stream integrity) because their presence might indicate sufficient habitat heterogeneity.

\section{Thresholds of physical forces limiting habitat suitability}

It is well known that changes in hydrological conditions in streams can directly affect habitat quality for epibenthic invertebrates (Sousa, 1984; Suren \& Jowett, 2006; Dewson et al., 2007). When stream waters exceed a certain flow rate, the higher power results in a more homogenized sediment condition and low accumulations of fine organic materials (leaves and detritus) in sheltered areas (Shvidchenko et al., 2001). Similarly, sedimentation increases with slow flow and the accumulation of fine sediments leads to homogenized sediment conditions as well. Such lowering of habitat complexity may consequently exclude taxa that depend on specific environmental conditions that are no longer available (e.g., those with fine substrate requirements or specific feeding behaviors (Graeber et al., 2013; Lorenz et al., 2016b; Stoll et al. 2016)). Therefore, river rehabilitation planning should seek to create a diverse and heterogeneous flow environment (Kakouei et al., 2017), which is expected to generate more complex habitat conditions (Lorenz et al., 2016a). 
River rehabilitation projects typically enhance physical and hydraulic habitat complexity to increase in-stream biodiversity (Milner \& Gilvear, 2012). However, for 78

442

443 restoration projects reviewed by Palmer et al. (2010), only two resulted in an increase in invertebrate diversity. Palmer et al. (2010) attributed the failure to meet species diversity targets to the focusing of the project almost exclusively on improving habitat structure to increase species diversity at the expense of improving other, potentially more important environmental conditions (Lake, 2000; McCabe \& Gotelli, 2000; Ward \& Tockner, 2001; Menninger \& Palmer, 2006; Muotka \& Syrjänen, 2007; Warfe et al., 2008). The restorations that focused exclusively on habitat might have failed because suitable sediment sizes (a reflection of promoting an appropriate shear stress) may not have been created, especially if the underlying hydromorphological processes were not addressed. The hydraulic threshold for biota we estimated in this study might be helpful in guiding future rehabilitation planning focused on improving in-stream biodiversity, even though several species we examined may have hydraulic preferences exceeding $0.64 \mathrm{~N} \mathrm{~m}^{-2}$.

\section{$\underline{\text { Rehabilitation implications }}$}

Our synthesis was focused on identifying the response of stream epibenthic biota (invertebrates) to hydromorphological and physical forces that might limit habitat suitability. Therefore, our main objective was to compile all available data on invertebrate habitat tolerances relative to shear stress and substrate size to test the relationship between preferred shear stresses and preferred sediment sizes.

River rehabilitation must take into account a myriad of potential competing factors, such as dredging and channelization for navigation, erosion control, and water extraction, all of which typically hamper hydromorphological processes in streams (sediment erosion, sediment transport downstream, and sediment sorting, large wood accumulation). In addition, 
water managers and rehabilitation planners should consider flood protection and bank stability when they identify rehabilitation targets, both of which can constrain possible restoration targets. Under such constraints, successful river rehabilitation will benefits from precise information on preferred and tolerated sediment or substrate size distributions and shear stress thresholds so that restorations can both incorporate safety requirements into the plan and optimize ecological improvements.

We found that riverine benthic invertebrates inhabit a wide range of substrate sizes $(0.05-400 \mathrm{~mm})$ and hydraulic conditions (shear stresses of $0.13-3.67 \mathrm{~N} \mathrm{~m}^{-2}$ ). This suggests that to maximize biodiversity, a wide range of physical and hydraulic habitat heterogeneity can be considered when planning and designing instream rehabilitation projects. Although hydraulic and substrate preferences did not significantly vary among species within the same genus or family, impact assessment and restoration planning should seek to define appropriate indicator taxa at the species level whenever possible. This is because using higher taxonomic groups may incorporate too much variability for defining rehabilitation targets. That is, the member species may have opposing requirements and/or flow thresholds and we do not yet know the habitat requirements of all those species. However, if detailed information on habitat preferences of some invertebrate species is unavailable, using currently known preferences at the family scale can be used to define restoration targets conditions or evaluate restoration success.

Physical and hydraulic habitat heterogeneity and complexity are commonly viewed as the main factors structuring invertebrate communities. Our synthesis of the literature demonstrated that a part of the stream invertebrate fauna may be affected to a higher extent by additional environmental factors, such as dissolved oxygen availability and the presence/absence of food resources, than by physical and hydraulic constrains. Therefore, many of the weak biotic responses reported in the restoration literature may have been 
resulted from ecological stresses (e.g., oxygen concentrations or food resources) not being 491 adequately addressed, stresses that are independent of creating adequate physical 492 hydromorphological conditions (e.g., habitat structure) (Palmer et al., 2010; Bernhardt et al., 493 2005; Barnes et al., 2013; Haase et al., 2013).

494

495 Acknowledgements

496 We thank Daniel Graeber for helpful comments on statistics and an anonymous reviewer for 497 his help in linguistic editing of the manuscript. This study was supported by the project 498 REFORM that received funding from the European Union's Seventh Programme for 499 Research, Technological Development and Demonstration under Grant Agreement No. 500282656. 


\section{References}

Allan, J. D. \& M. M. Castillo, 2007. Stream Ecology: Structure and Function of Running Waters. Springer, Dordrecht.

Ambühl, H., 1960. Die Bedeutung der Strömung als ökologischer Faktor. PhD, ETH Zürich.

Angradi, T. R., 1999. Fine Sediment and Macroinvertebrate Assemblages in Appalachian Streams: A Field Experiment with Biomonitoring Applications. Journal of the North American Benthological Society 18: 49-66.

Barnes, J. B., I. P. Vaughan \& S. J. Ormerod, 2013. Reappraising the effects of habitat structure on river macroinvertebrates. Freshwater Biology 58: 2154-2167.

Beauger, A., N. Lair, P. Reyes-Marchant \& J. L. Peiry, 2006. The distribution of macroinvertebrate assemblages in a reach of the River Allier (France), in relation to riverbed characteristics. Hydrobiologia 571: 63-76.

Bérg, K., P. Jónasson \& K. W. Ockelmann, 1962. The respiration of some animals from the Profundal Zone of a lake. Hydrobiologia 19: 1-39.

Bernhardt, E. S., M. A. Palmer, J. D. Allan, G. Alexander, K. Barnas, S. S. Brooks, J. Carr, S. Clayton, C. Dahm, J. Follstad-Shah, D. Galat, S. Gloss, P. Goodwin, D. Hart, B. Hassett, R. Jenkinson, S. Katz, G. M. Kondolf, P. S. Lake, R. Lave, J. L. Meyer, T. K. O'Donnell, L. Pagano, B. Powell \& E. Sudduth, 2005. Synthesizing U.S. river restoration efforts. Science 308: 636-637.

Birk, S., W. Bonne, A. Borja, S. Brucet, A. Courrat, S. Poikane, A. G. Solimini, W. Van de Bund, N. Zampoukas \& D. Hering, 2012. Three hundred ways to assess Europe's surface waters: an almost complete overview of biological methods to implement the Water Framework Directive. Ecological Indicators 18: 31-41. 
Borchardt, D., 1993. Effects of flow and refugia on drift loss of benthic macroinvertebrates: implications for habitat restoration in lowland streams. Freshwater Biology 29: 221227.

Bradbeer, P. A. \& A. A. Savage, 1980. Some observations on the distribution and life history of Caenis robusta Eaton (Ephemeroptera) in Cheshire and North Shropshire, England. Hydrobiologia 68: 87-90.

Brodersen, K. P., O. L. E Pedersen, I. R. Walker \& M. T. Jensen, 2008. Respiration of midges (Diptera; Chironomidae) in British Columbian lakes: oxy-regulation, temperature and their role as palaeo-indicators. Freshwater Biology 53: 593-602.

Buss, D., D. Baptista, J. Nessimian \& M. Egler, 2004. Substrate specificity, environmental degradation and disturbance structuring macroinvertebrate assemblages in neotropical streams. Hydrobiologia 518: 179-188.

Chessman; B. C., K. A. Fryirs \& G. J. Brierly, 2006. Linking geomorphic character, behaviour and condition to fluvial biodiversity: implications for river management. Aquatic Conservation 16: 267-288.

Chester, E. T. \& B. J. Robson, 2011. Drought refuges, spatial scale and recolonisation by invertebrates in non-perennial streams. Freshwater Biology 56: 2094-2104.

Culp, J. M., S. J. Walde \& R. W. Davies, 1983. Relative Importance of Substrate Particle Size and Detritus to Stream Benthic Macroinvertebrate Microdistribution. Canadian Journal of Fisheries and Aquatic Sciences 40: 1568-1574.

Davis, J. A. \& L. A. Barmuta, 1989. An ecologically useful classification of near-bed flows in streams and rivers. Freshwater Biology 21: 271-282.

Dewson, Z. S., A. B. W. James \& R. G. Death, 2007. A review of the consequences of decreased flow for instream habitat and macroinvertebrates Journal of the North American Benthological Society 26: 401-415. 
Dolédec, S., N. Lamouroux, U. Fuchs \& S. Mérigoux, 2007. Modelling the hydraulic preferences of benthic macroinvertebrates in small European streams. Freshwater Biology 52: 145-164.

Downes, B. J. \& J. Lancaster, 2010. Does dispersal control population densities in advectiondominated systems? A fresh look at critical assumptions and a direct test. Journal of Animal Ecology 79: 235-248.

Downes, B. J., P. S. Lake, A. Glaister \& N. R. Bond, 2006. Effects of sand sedimentation on the macroinvertebrate fauna of lowland streams: are the effects consistent? Freshwater Biology 51: 144-160.

Duan, X., Z. Wang, M. Xu \& K. Zhang, 2009. Effect of streambed sediment on benthic ecology. International Journal of Sediment Research 24: 325-338.

EEA, 2000. European waters - Assessment of stauts and pressures. European Environmental Agency, Copenhagen.

Elliott, J. M., 2008. The ecology of riffle beetles (Coleoptera: Elmidae). Freshwater Reviews 1: 189-203.

Elosegi, A. \& S. Sabater, 2013. Effects of hydromorphological impacts on river ecosystem functioning: a review and suggestions for assessing ecological impacts. Hydrobiologia 712: $129-143$.

Fehér, J., J. Gáspár, K. Szurdiné-Veres, A. Kiss, P. Kristensen, M. Peterlin, L. Globevnik, T. Kirn, S. Semerádova, A. Künitzer, U. Stein, K. Austnes, C. Spiteri, T. Prins, E. Laukkonen \& A.-S. Heiskanen, 2012. Hydromorphological alterations and pressures in European rivers, lakes, transitional and coastal waters. Thematic assessment for EEA Water 2012 Report. European Topic Centre on Inland, Coastal and Marine Waters, Prague, ETC/ICM Technical Report 2/2012. 
573 Feld, C. K., S. Birk, D. C. Bradley, D. Hering, J. Kail, A. Marzin, A. Melcher, D. Nemitz, M. L. Pedersen, F. Pletterbauer, D. Pont, P. F. M. Verdonschot \& N. Friberg, 2011. From natural to degraded rivers and back again: a test of restoration ecology theory and practice. Advances in Ecological Research 44: 119-209.

Feld, C. K. \& D. Hering, 2007. Community structure of function: effects of environmental stress on benthic macroinvertebrates at different spatial scales. Freshwater Biology 52: 1380-1399.

Fox, J. \& S. Weisberg, 2011. An $\{\mathrm{R}\}$ Companion to Applied Regression, Second Edition. Thousand Oaks

CA: Sage.

URL: http://socserv.socsci.mcmaster.ca/jfox/Books/Companion

Frissell, C. A., W. J. Liss, C. E. Warren \& M. D. Hurley, 1986 A hierarchical framework for stream habitat classification: viewing streams in a watershed context. Environmental Management 10: 199-214.

Gabel F., X.-F. Garcia, I. Schnauder \& M. Pusch, 2012. Effects of ship-induced waves on littoral benthic invertebrates. Freshwater Biology 57: 2425-2435.

Gibbins C., R. J. Batalla \& D. Vericat, 2010. Invertebrate drift and benthic exhaustion during disturbance: Response of mayflies (Ephemeroptera) to increasing shear stress and river-bed instability. River Research and Applications 26: 499-511.

Gore, J. A., 1996. Responses of aquatic biota to hydrological change. River Biota, Diversity and Dynamics (eds G.E. Petts \& P. Calow), pp. 209-230. Blackwell Science, Oxford.

Graeber, D., M. Pusch, S. Lorenz \& Brauns, 2013. Cascading effects of flow reduction on the benthic invertebrate community in a lowland river. Hydrobiologia 717: 147-159.

Graf, W., A. W. Lorenz, J. M. Tierno de Figueroa, S. Lücke, M. J. López-Rodríguez \& C. Davie, 2009. Distribution and Ecological Preferences of European Freshwater Organisms. Pensoft Publishers, Sofia-Moscow. 
Graf, W., A. W. Lorenz, J. M. Tierno de Figueroa, S. Lücke, M. J. López-Rodríguez, J. Murphy \& A. Schmidt-Kloiber, 2007. Plecoptera Indicator Database. Euro-limpacs project, Workpackage 7 - Indicators of ecosystem health, Task 4, www.freshwaterecology.info, version 5.0 (accessed on 29.11.2012).

Growns, I. O. \& J. A. Davis. 1994. Longitudinal changes in near-bed flows and macroinvertebrate communities in a Western Australian stream. Journal of the North American Benthological Society 13: 417-438.

Haase, P., D. Hering, S. C. Jähnig, A. W. Lorenz \& A. Sundermann, 2013. The impact of hydromorphological restoration on river ecological status: a comparison of fish, benthic invertebrates, and macrophytes. Hydrobiologia 704: 475-488.

Hart D. \& C. Finelli, 1999. Physical-Biological Coupling in Streams: The Pervasive Effects of Flow on Benthic Organisms. Annual Review of Ecology and Systematics 30: 363-395.

Hauer, C., G. Unfer, W. Graf, P. Leitner, B. Zeiringer \& H. Habersack, 2012. Hydromorphologically related variance in benthic drift and its importance for numerical habitat modelling. Hydrobiologia 683: 83-108.

Hering, D., J. Arovitta, A. Baattrupp-Pedersen, K. Brabec, T. Buijze, F. Ecke, N. Friberg, M. Gielczewski, K. Januschke, J. Kohler, B. Kupilas, A. Lorenz, S. Muhar, A. Paillex, M. Poppe, T. Schmidt, S. Schmutz, J. E. Vermaat, P. Verdonschot \& R. Verdonschot, 2015. Contrasting the roles of section length and instream habitat enhancement for river restoration success: a field study on 20 European restoration projects. Journal of Applied Ecology 52: 1518-1527.

Holomuzki, J. R. \& B. J. F. Biggs, 2000. Taxon-Specific Responses to High-Flow Disturbance in Streams: Implications for Population Persistence. Journal of the North American Benthological Society 19: 670-679. 
Imbert, J. B. \& J. Perry, 2000. Drift and benthic invertebrate responses to stepwise and abrupt increases in non-scouring flow. Hydrobiologia 436: 191-208.

Int Panis, L., L. Bervoets \& R. Verheyen, 1994. The spatial distribution of Caenis horaria (L.,1758) (Caenidae, Ephemeroptera) in a pond in Niel (Belgium). Bulletin et annales de la Société entomologique de Belgique 131: 47-52.

Jähnig, S. C. \& A. W. Lorenz, 2008. Substrate-specific macroinvertebrate diversity patterns following stream restoration. Aquatic Sciences - Research Across Boundaries 70: 292303.

Janauer, G. A., U. Schmidt-Mumm \& B. Schmidt, 2010. Aquatic macrophytes and water current velocity in the Danube River. Ecological Engineering 36: 1138-1145.

Johnson, R. K., 1995. The indicator concept in freshwater biomonitoring. Chironomids: From Genes to Ecosystems (ed. P. Cranston), pp. 11-27. CSIRO Publications, Melbourne.

Jowett, I. G., 2000. Flow management. New Zealand Stream Invertebrates: Ecology and Implications for Management (eds K.J. Collier \& M.J. Winterbourn), pp. 289-312. New Zealand Limnological Society, Christchurch.

Jowett, I. G., 2003. Hydraulic constraints on habitat suitability for benthic invertebrates in gravel-bed rivers. River Research and Applications 19: 495-507.

Kail, J. \& D. Hering, 2009. The influence of adjacent stream reaches on the local ecological status of Central European mountain streams. River Research and Applications 25: 537-550.

Kakouei, K., J. Kiesel, J. Kail, M. Pusch \& S. C. Jähnig, 2017. Quantitative hydrological preferences of benthic stream invertebrates in Germany. Ecological Indicators 79: 163-172.

Krumbein, W. C. \& L. L. Sloss. 1963 Stratigraphy and Sedimentation (eds W.C. Krumbein \& L.L. Sloss). Freeman \& Co, San Francisco. 
Lake, P. S., 2000. Disturbance, patchiness, and diversity in streams. Journal of the North American Benthological Society 19: 573-592.

Lamouroux, N., S. Mérigoux, S. Dolédec \& T. H. Snelder, 2013. Transferability of hydraulic preference models for aquatic macroinvertebrates. River Research and Applications 29: 933-937.

Lange, C., M. Schneider, M. Mutz, M. Haustein, M. Halle, M. Seidel, H. Sieker, C. Wolter \& R. Hinkelmann, 2015. Model-based design for resoration of a small urban river. Journal of Hydro-environment Research 9: 226-236.

Lorenz, A. W., Jähnig, S. C. \& D. Hering, 2009. Re-Meandering German Lowland Streams: Qualitative and Quantitative Effects of Restoration Measures on Hydromorphology and Macroinvertebrates. Environmental Management 44: 745-754.

Lorenz, A. W. \& C. K. Feld. 2013. Upstream river morphology and riparian land use overrule local restoration effects on ecological status assessment. Hydrobiologia 704: 489-501.

Lorenz, S, V. Martinez-Fernández, C. Alonso, E. Mosselman, D. García de Jalón, M. González del Tánago, B. Belletti, D. Hendriks \& C. Wolter, 2016a. Fuzzy cognitive mapping for predicting hydromorphological responses to multiple pressures in rivers. Journal of Applied Ecology 53: 559-566.

Lorenz, S., M. Leszinski \& D. Graeber, 2016b. Meander reconnection method determines restoration success for macroinvertebrate communities in a German lowland river. International Review of Hydrobiology 101: 123-13.

Lyche-Solheim, A., C. K. Feld, S. Birk, G. Phillips, L. Carvalho, G. Morabito, U. Mischke, N. Willby, M. Søndergaard, S. Hellsten, A. Kolada, M. Mjelde, J. Böhmer, O. Miler, M. Pusch, C Argillier, E. Jeppesen, T. Lauridsen \& S. Poikane, 2013. Ecological status assessment of European lakes: a comparison of metrics for phytoplankton, macrophytes, benthic invertebrates and fish. Hydrobiologia 704: 57-74. 
672 Mackie, G. L., 2007. Biology of freshwater corbiculid and sphaeriid clams of North America.

673

674

675

676

677

678

679

680

681

682

683

684

685

686

687

688

689

690

691

692

693

694

695 Ohio Biological Survey Bulletin New Series, Columbus.

Maxted, J. R., B. F. Evans \& M. R. Scarsbrook, 2003. Development of standard protocols for macroinvertebrate assessment of soft-bottomed streams in New Zealand. New Zealand Journal of Marine and Freshwater Research 37: 793-807.

McCabe, D. J. \& N. J. Gotelli, 2000. Effects of disturbance frequency, intensity, and area on assemblages of stream macroinvertebrates. Oecologia 124: 270-279.

Meier, C., P. Haase, P. Rolauffs, K. Schindehütte, F. Schöll, A. Sundermann \& D. Hering, 2006. Methodisches Handbuch Fließgewässerbewertung. Handbuch zur Untersuchung und Bewertung von Fließgewässern auf der Basis des Makrozoobenthos vor dem Hintergrund $\quad$ der $\quad$ EGWasserrahmenrichtlinie. http://www.fliessgewaesserbewertung.de/downloads/abschlussbericht 20060331 anhang IX.pdf

Menninger, H. L. \& M. A. Palmer, 2006. Restoring ecological communities: from theory to practice. Foundations of Restoration Ecology (eds D.A. Falk, M.A. Palmer \& J.B. Zedler), pp. 88-112. Island Press, Washington, DC.

Mérigoux, S. \& S. Dolédec, 2004. Hydraulic requirements of stream communities: a case study on invertebrates. Freshwater Biology 49: 600-613.

Mérigoux, S., N. Lamouroux, J.-M. Olivier \& S. Dolédec, 2009. Invertebrate hydraulic preferences and predicted impacts of changes in discharge in a large river. Freshwater Biology 54: 1343-1356.

Miller, S. W., P. Budy \& J. C. Schmidt, 2010. Quantifying macroinvertebrate responses to instream habitat restoration: applications of meta-analysis to river restoration. Restoration Ecology 18: 8-19. 
Milner, V. S. \& D. J. Gilvear, 2012. Characterization of hydraulic habitat and retention across different channel types; introducing a new field-based technique. Hydrobiologia 694: 219-233.

Milner, V. S., N. J. Willby, D. J. Gilvear \& C. Perfect, 2015. Linkages between reach-scale physical habitat and invertebrate assemblages in upland streams. Marine and Freshwater Research 66: 438-448.

Möbes-Hansen, B. \& J. A. Waringer, 1998. The influence of hydraulic stress on microdistribution patterns of zoobenthos in a sandstone brook (Weidlingbach, Lower Austria). International Review of Hydrobiology 83: 381-396.

Monk, W. A., P. J. Wood, D. M. Hannah, C. A. Extence, R. P. Chadd \& M. J. Dunbar, 2012. How does macroinvertebrate taxonomic resolution influence ecohydrological relationships in riverine ecosystems? Ecohydrology 5: 36-45.

Muotka, T. \& J. Syrjänen, 2007. Changes in habitat structure, benthic invertebrate diversity, trout populations and ecosystem processes in restored forest streams: a boreal perspective. Freshwater Biology 52: 724-737.

Pabst, S., N. Scheifhacken, J. Hesselschwerdt \& K. M. Wantzen, 2008. Leaf litter degradation in the wave impact zone of a pre-alpine lake. Hydrobiologia 613: 117-131.

Palmer, M. A., H. L. Menninger \& E. Bernhardt, 2010. River restoration, habitat heterogeneity and biodiversity: a failure of theory or practice? Freshwater Biology 55: 205-222.

Pan, B. Z., Z. Y. Wang \& M. Z. Xu, 2012. Macroinvertebrates in abandoned channels: assemblage characteristics and their indications for channel management. River Research and Applications 28: 1149-1160.

Poff, N. L., J. D. Allan, M. B. Bain, J. R. Karr, K. L. Prestegaard, B. D. Richter, R. E. Sparks, \& J. C. Stromberg, 1997. The natural flow regime. Bioscience 47:769-784. 
Poole, W. \& K. Stewart, 1976. The vertical distribution of macrobenthos within the substratum of the Brazos river, Texas. Hydrobiologia 50: 151-160.

Power, M. E., J. R. Holomuzki \& R. L. Lowe, 2013. Food webs in Mediterranean rivers. Hydrobiologia 719: 119-136.

Quinlan, R. \& J. P. Smol, 2001. Chironomid-based inference models for estimating end-ofsummer hypolimnetic oxygen from south-central Ontario shield lakes. Freshwater Biology 46: 1529-1551.

Rabeni, C. F. \& G. W. Minshall, 1977. Factors affecting micro-distribution of stream benthic insects. Oikos 29: 33-43.

Rader, R. \& J. V. McArthur, 1995. The relative importance of refugia in determining the drift and habitat selection of predaceous stoneflies in a sandy-bottomed stream. Oecologia 103: 1-9.

Reice, S. R., 1980. The Role of Substratum in Benthic Macroinvertebrate Microdistribution and Litter Decomposition in a Woodland Stream. Ecology 61: 580-590.

Robson, B. J. \& B. D. Mitchell, 2010. Metastability in a river subject to multiple disturbances may constrain restoration options. Marine and Freshwater Research 61: 778-785.

Robson, B. J. \& E. T. Chester, 1999. Spatial patterns of invertebrate species richness in a river: the relationship between riffles and microhabitats. Austral Ecology 24: 599-607.

Robson, B. J., E. T. Chester \& J. A. Davis, 1999. Manipulating the intensity of near-bed turbulence in rivers: effects on benthic invertebrates. Freshwater Biology 42: 645-653.

Roni, P., K. Hanson, T. Beechie, G. Pess, M. Pollock \& D. M. Bartley, 2005. Habitat Rehabilitation for Inland Fisheries. FAO Fisheries Technical Paper, 484, FAO, Rome.

Roni, P., K. Hanson, K. \& T. Beechie, 2008. Global review of the physical and biological effectiveness of stream habitat rehabilitation techniques. North American Journal of Fisheries Management 28: 856-890. 
Schmidt-Kloiber, A. \& D. Hering, 2015. www.freshwaterecology.info - An online tool that unifies, standardises and codifies more than 20,000 European freshwater organisms and their ecological preferences. Ecological Indicators 53: 271-282.(

Schnauder, I., S. Rudnick, X.-F. Garcia \& J. Aberle, 2010. Incipient Motion and Drift of Benthic Invertebrates in Boundary Shear Layers. Riverflow 2010 (eds Dittrich, Koll, Aberle \& Geisenhainer). Bundesanstalt für Wasserbau.

Schröder, M., J. Kiesel, A. Schattmann, S. C. Jähnig, A. W. Lorenz, S. Kramm, H. KeizerVlek, P. Rolauffs, W. Graf, P. Leitner \& D. Hering, 2013. Substratum associations of benthic invertebrates in lowland and mountain streams. Ecological Indicators 30: 178189.

Shvidchenko, A. B, G. Pender \& T. B. Hoey, 2001. Critical shear stress for incipient motion of sand/gracel streambeds. Water Resources Research 37: 2273-2283.

Singh, J., O. P. Gusain \& M. P. Gusain, 2010. Benthic insect-substratum relationship along an altitudinal gradient in a Himalayan stream, India. Internation Journal of Ecology and Environmental Sciences 36: 215-231.

Söhngen, B., J. Koop, S. Knight, J. Rythönen, P. Beckwith, N. Ferrari, J. Iribarren, T. Keevin, C. Wolter \& S. Maynord, 2008. Considerations to Reduce Environmental Impacts of Vessels. Brussels: PIANC, PIANC Report 99.

Sonderegger, D., 2012. SiZer: SiZer: Significant Zero Crossings. R package version 0.1-4. https://CRAN.R-project.org/package=SiZer.

Sousa, W. P., 1984. The role of disturbance in natural communities. Annual Review of Ecology and Systematics 15: 353-391.

Sponseller, R. A., E. F. Benfield \& H. M. Valett, 2001. Relationships between land use, spatial scale and stream macroinvertebrate communities. Freshwater Biology 46: $1409-1424$. 
Statzner, B., 1981. The relationship between "hydraulic stress" and microdistributions of benthic macroinvertebrates in a lowland running water system, the Schierenseebrooks (North Germany). Archiv für Hydrobiologie 91: 192-218.

Statzner, B., J. A. Gore \& V. H. Resh, 1988. Hydraulic Stream Ecology: Observed Patterns and Potential Applications. Journal of the North American Benthological Society 7: 307-360.

Statzner, B., F. Kohmann \& A. G. Hildrew, 1991. Calibration of FST-hemispheres against bottom shear stress in a laboratory flume. Freshwater Biology 26: 227-231.

Stoll, S., P. Breyer, J.D. Tonkin, D. Früh \& P. Haase, 2016. Scale-dependent effects of river habitat quality on benthic invertebrate communities-implications for stream restoration practice. Science of the Total Environment 553: 495-503.

Sundermann, A., C. Antons, N. Cron, A. W. Lorenz, D. Hering \& P. Haase, 2011a. Hydromorphological restoration of running waters: effects on benthic invertebrate assemblages. Freshwater Biology 56: 1689-1702.

Sundermann, A., Stoll, S. \& P. Haase, 2011b. River restoration success depends on the species pool of the immediate surroundings. Ecological Applications 21: 1962-1971.

Sundermann, A., Gerhardt, M., Kappes, H \& P. Haase, 2013. Stressor prioritization in riverine ecosystems: Benthic invertebrates assemblages are shaped by water quality rather than by local habitat structure. Ecological Indicators 27: 83-96.

Suren, A. M. \& I. G. Jowett, 2006. Effects of floods versus low flows on invertebrates in a New Zealand gravel-bed river. Freshwater Biology 51: 2207-2227.

Timm, H., K. Mardi \& T. Möls, 2008. Macroinvertebrates in Estonian streams: the effects of habitat, season, and sampling effort on some common metrics of biological quality. Estonian Journal of Ecology 57: 37-57. 
Tolkamp, H., 1982. Microdistribution of macroinvertebrates in lowland streams. Hydrobiological Bulletin 16: 133-148.

Tonkin, J., Stoll, S., Sundermann, A. \& P. Haase, 2014. Dispersal distance and the pool of taxa, but not barriers, determine the colonisation of restored river reaches by benthic invertebrates. Freshwater Biology 59: 1843-1855.

Tyler, E.H.M., P.J. Somerfield, E. V. Berghe, J. Bremner, E. Jackson, O. Langmead, M. L. D. Palomares \& T. J. Webb, 2012. Extensive gaps and biases in our knowledge of a wellknown fauna: implications for integrating biological traits into macroecology. Global Ecology and Biogeography 21 922-934:

USEPA (United States Environment Protection Agency), 2009. National Water Quality Inventory: Report to Congress. 2004 Reporting Cycle. United States Environmental Protection Agency, Office of Water, Washington, DC.

Vaughan, I., M. Diamond, A. Gurnell, K. A. Hall, A. Jenkins, N. J. Milner, L. A. Naylor, D. A. Sear, G. Woodward \& S. J. Ormerod, 2009. Integrating Ecology with hydromorphology: a priority for river science and managment. Aquatic Conservation: Marine and Freshwater Ecosystems 19: 113-125.

Verdonschot, P. F. M., B. M. Spears, C. K. Feld, S. Brucet, H. Keizer-Vlek, A. Borja, M. Elliott, M. Kernan \& R. K. Johnson, 2013. A comparative review of recovery processes in rivers, lakes, estuarine and coastal waters. Hydrobiologia 704: 453-474.

Ward, J. V. \& K. Tockner, 2001. Biodiversity: towards a unifying theme for river ecology. Freshwater Biology 46: 807-819.

Warfe, D. M., L. A. Barmuta \& S. Wotherspoon, 2008. Quantifying habitat structure: surface convolution and living space for species in complex environments. Oikos 117: 17641773. 
Waters, T. F., 1995. Sediment in Streams: Sources, Biological Effects, and Controls. American Fisheries Society, Bethesda, Maryland.

Weigel, B. M., L. Z. Wang, P. W. Rasmussen, J. T. Butcher, P. M. Stewart, T. P. Simon \& M. J. Wiley, 2003. Relative influence of variables at multiple spatial scales on stream macroinvertebrates in the Northern Lakes and forest ecoregion, USA. Freshwater Biology 48: 1440-1461.

Venables, W. N. \& B. D. Ripley, 2002. Modern Applied Statistics with S. Fourth Edition. Springer, New York. ISBN 0-387-95457-0.

Williams, D. D. \& H. B. N. Hynes, 1974. The occurrence of benthos deep in the substratum of a stream. Freshwater Biology 4: 507-524.

Williams, D. D. \& K. A. Moore, 1986. Microhabitat selection by a stream-dwelling amphipod - a multivariate-analysis approach. Freshwater Biology 16: 115-122.

Wolter, C., 2010. Functional vs scenic restoration - challenges to improve fish and fisheries in urban waters. Fisheries Management and Ecology 17: 176-185.

Wolter, C. \& R. Arlinghaus, 2003. Navigation impacts on freshwater fish assemblages: the ecological relevance of swimming performance. Reviews in Fish Biology and Fisheries 13: 63-89.

Wolter, C., R. Arlinghaus, A. Sukhodolov \& C. Engelhardt, 2004. A model of navigation induced currents in inland waterways and implications for juvenile fish displacement. Environmental Management 34: 656-668.

Wolter, C., S. Lorenz, S. Scheunig, C. Schomaker, V. Martinez-Fernandez, C. Alonso, D. Garcia de Jalon, M. Gonzalez del Tanago, E. Mosselman, D. Hendriks \& B. Beletti, 2015. Hydromorphic change and biotic response challenge efficient river rehabilitation. In: Angelopoulos, N., T. Buijse, M. van Oorschot \& E. Kampa [eds.] Proceedings of the International Conference on River and Stream Restoration "Novel 

7.5. p 79-84.

846 
848 Additional supporting information may be found in the online version of this article:

849

850 Online Resource 1. Hydraulic preferences of benthic invertebrates.

851 Online Resource 2. Hat values and Cook's distance calculated from the linear regression

852 models on squareroot-transformed data on substrate vs. hydraulic preferences of benthic 853 invertebrates.

854 Online Resource 3. Substrate and grain size preferences of benthic invertebrates.

855 Online Resource 4. Critical shear stress thresholds detaching and dislodging invertebrates.

856

857 
859 Table 1: Sediment grain sizes of substrate classes examined in this study.

860

\begin{tabular}{cc}
\hline Substrate class & Sediment grain size $[\mathrm{mm}]$ \\
\hline 0 & $256 \leq 128$ \\
1 & $128 \leq 64$ \\
2 & $64 \leq 32$ \\
3 & $32 \leq 16$ \\
4 & $16 \leq 8$ \\
5 & $8 \leq 4$ \\
6 & $4 \leq 2$ \\
7 & $2 \leq 1$ \\
8 & $1 \leq 0.5$ \\
9 & $0.5 \leq 0.25$ \\
10 & $0.25 \leq 0.125$ \\
11 & $0.125 \leq 0.05$ \\
\hline
\end{tabular}

861

862 
Fig. 1: Hydraulic preferences of epibenthic invertebrates (Coleoptera, Diptera, Plecoptera, Trichoptera, and Ephemeroptera), pooled by genus or family. The taxonomic identity for each group are provided as examples and do not represent any qualitative or quantitative ranking within the group. Whisker plots represent mean \pm 1 standard deviation.

Fig. 2: Regression model of substrate preferences of benthic invertebrates from class 0 to 11 plotted against their hydraulic preferences (solid circles). Outliers (open circles) indicate taxa not primarily determined by hydromorphologic conditions. Solid red line shows results of the

873 piecewise regression model indicating the significant inflection point (change point) where shear stress limits habitat suitability. The dashed line shows the linear regression model following the substrate size/shear stress preference relationship, excluding outliers $\left(\operatorname{adj} . \mathrm{r}^{2}=\right.$ $0.36, \mathrm{p}=0.002$ ). The dashed line at the top of graph marks the threshold between substrate class 11 and detritus (Det.) as preferred substrate.

878

879 Fig. 3: Species sensitivity distribution of benthic invertebrate taxa against hydraulic preference $\left(\mathrm{N} \mathrm{m}^{-2}\right)$. Different colors indicate different taxonomic groups. Solid red line indicates fitted lognormal distribution and dashed lines indicate 95\% confidence intervals. Solid grey lines indicate the shear stress threshold where $39 \%$ of the 188 taxa analyzed become potentially affected by limited habitat suitability (i.e., when the threshold of $0.64 \mathrm{~N}$ 